\title{
Molecular Gears: A Pair of DNA Circles Continuously Rolls against Each Other
}

\author{
Ye Tian and Chengde Ma** \\ Purdue University, Department of Chemistry, 560 Oval Drive, West Lafayette, Indiana 47907
}

Received June 13, 2004; E-mail: mao@purdue.edu

This communication reports a pair of molecular gears that consist of DNA and are fueled by DNA. Each gear is a DNA nanocircle with a diameter of $6.7 \mathrm{~nm}$. The motion energy is from DNA hybridization. The rolling direction could be controlled by arbitrary instruction.

DNA has been explored for building nanostructures because of its excellent molecular recognition capability and predictable secondary structures. ${ }^{1}$ A number of DNA nanomachines have been developed in the last six years. ${ }^{2}$ The motion includes rotation, open and close, extension and contraction, and walking. Except walking, ${ }^{2 k, l}$ all other motions are quite simple. A challenge logically arises as to what complicated motions DNA machines can perform. As one step toward addressing this challenge, we have decided to construct molecular gears. For macroscale machines, gears are essential components whose functions include: reversing the direction of rotation, increasing or decreasing the speed of rotation, moving rotational motion to a different axis, and keeping the rotation of two axes synchronized. ${ }^{3}$ We would expect nanogears to play similar roles in complex nanomachines.

This communication reports a simple gear system that contains two gears: A and B (Figure 1). Each gear is composed of four DNA single strands: one central circular strand (C) and three peripheral linear strands $\left(\mathrm{P}_{i, i=1,2,3}\right)$. The two gears share the same $\mathrm{C}$ strand, but have different sets of $\mathrm{P}$ strands $\left(\mathrm{P}_{i}^{\mathrm{A}}\right.$ and $\left.\mathrm{P}_{i}^{\mathrm{B}}\right)$. The four strands of each gear are organized into a DNA duplex circle with three single-stranded teeth $\left(\mathrm{T}_{i, i=1,2,3}\right)$. Gears A and B do not interact with each other by themselves; instead, they are brought together by linker strands $\left(\mathrm{L}_{i, i}, 1,2,3\right)$ and separated by removal strands $\left(\mathrm{R}_{i, i=1,2,3}\right)$. One $\mathrm{L}_{i}$ strand consists of three sections: $\mathrm{L}_{i}^{\mathrm{A}}$, $\mathrm{L}_{i}^{\mathrm{B}}$, and $\mathrm{L}_{i}^{\mathrm{R}} \cdot \mathrm{L}_{i}^{\mathrm{A}}$ is complementary to tooth $\mathrm{T}_{i}^{\mathrm{A}}$ of gear $\mathrm{A}$, and $\mathrm{L}_{i}^{\mathrm{B}}$ is complementary to tooth $\mathrm{T}_{i}^{\mathrm{B}}$ of gear $\mathrm{B}$. When strand $\mathrm{L}_{1}$ is added to the gears, $\mathrm{L}_{1}{ }^{\mathrm{A}}$ and $\mathrm{L}_{1}{ }^{\mathrm{B}}$ will base-pair with teeth $\mathrm{T}_{1}{ }^{\mathrm{A}}$ and $\mathrm{T}_{1}{ }^{\mathrm{B}}$, respectively. Thus, the two gears are linked at the first tooth position. At this stage, $L_{1}{ }^{R}$ remains unpaired. Strand $R_{1}$ is fully complementary to $L_{1}$, and they can form a long duplex $\left(L_{1} / R_{1}\right)$. When $R_{1}$ is added, $R_{1}$ first base-pairs with the unpaired $L_{1}{ }^{R}$ section and then gradually removes strand $\mathrm{L}_{1}$ from the gears through branch migration. The strand displacement strategy has been used in previously reported DNA nanomachines. ${ }^{2 \mathrm{~b}-\mathrm{h}, \mathrm{k}-\mathrm{m}}$ During all operations, the two gears are always linked, by either one or two L strands to make sure that the gears continuously roll against each other. The rolling direction can be controlled by controlling the tooth positions that are linked. A linking order of $1-1,2-2-2,3-3-$ $3,1-1$ will allow the gears to roll against each other for one full circle, where the numbers indicate the tooth positions that are linked. At the second state $(1,2)$ in this process, for example, the two circles are linked at both teeth 1 and 2 .

We assembled gears A and B separately and confirmed the formation of the individual gears by native polyacrylamide gel electrophoresis (PAGE, Figure 2). All DNA complexes appear as

11410 a J. AM. CHEM. SOC. 2004, 126, 11410-11411
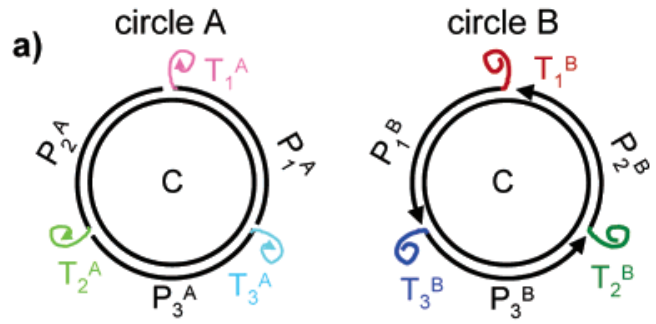

b)

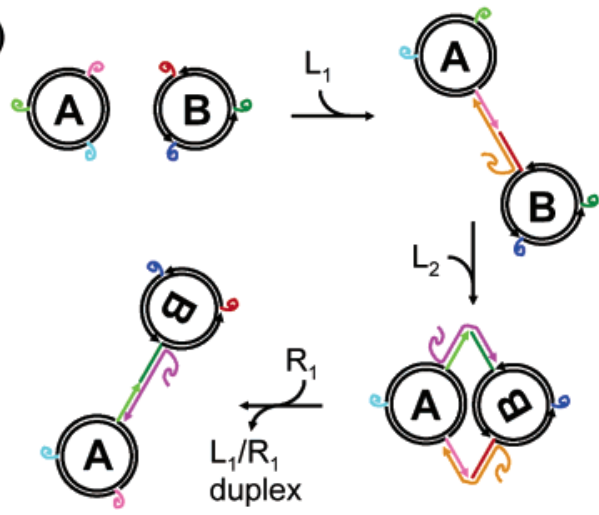

Figure 1. Scheme of the rolling process of gears. (a) Structures of the individual gears. C and P indicate DNA strands, and T indicates teeth. (b) Operation of the gears. L and $\mathrm{R}$ represent linker and removal strands, respectively. $L_{1}$ and $R_{1}$ are complementary to each other. Both circles remain intact during the rolling process. The only changed strands are the linker (L) and removal (R) strands. Note that no twisting motion will be generated to the central stands during the rolling process.

single sharp bands with expected mobility on the gel. The results indicate that the gears are stable structures.

The rolling process of the gears was initially analyzed by native PAGE (Figure 3). When being linked once or twice, a pair of gears has different molecular weight and adopts different conformations, thus exhibiting different electrophoretic mobilities. All three singlelinked gears are expected to have a similar mobility, and all three double-linked gears are expected to have a similar mobility. But the mobilities of the two groups are different. The expected mobility pattern is observed in the electrophoretic analysis and is consistent with the rolling process of the gears. All steps process very efficiently ( $>95 \%)$. However, if the ratio between the DNA stands is not exactly right, the error will accumulate in multiple rolling cycles and eventually will stop the gears.

To further characterize the rolling process, we used a ligation experiment and examined reporter strands (Figure 4). We labeled the $5^{\prime}$ ends of the three peripheral strands of gear $\mathrm{B}$ with $\mathrm{P}^{32}$, a radioactive isotope. When gears $\mathrm{A}$ and $\mathrm{B}$ are brought together by linker strand $\mathrm{L}_{i}$, the $3^{\prime}$ end of strand $\mathrm{P}_{i}^{\mathrm{A}}$ juxtaposes with the $5^{\prime}$ end of strand $\mathrm{P}_{i}^{\mathrm{B}}$. DNA ligase can covalently join $\mathrm{P}_{i}^{\mathrm{A}}$ and $\mathrm{P}_{i}^{\mathrm{B}}$ into a long strand $\mathrm{P}_{i}^{\mathrm{A}}+\mathrm{P}_{i}^{\mathrm{B}}$ (a reporter strand). The production of $\mathrm{P}_{i}^{\mathrm{A}}+$ $\mathrm{P}_{i}^{\mathrm{B}}$ reports whether gears $\mathrm{A}$ and $\mathrm{B}$ contact at tooth $i$. Only 


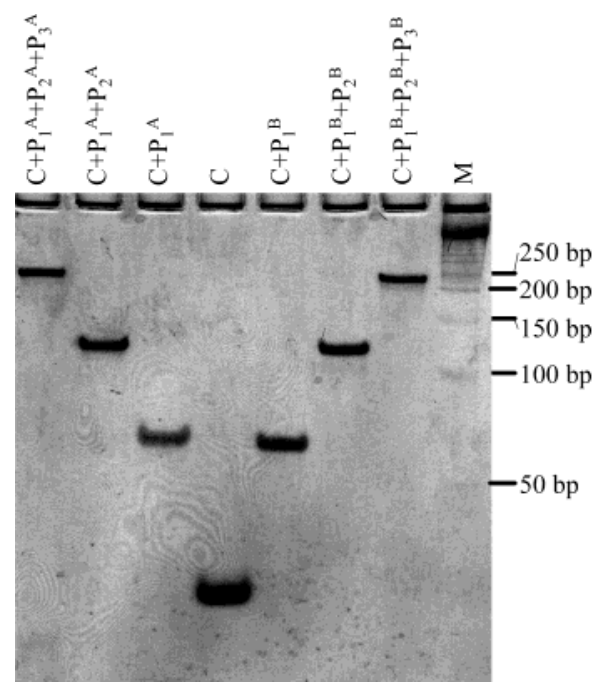

Figure 2. Formation of individual gears analyzed by $12 \%$ native PAGE. The content of each lane is indicated above the lane. Lane M contains a series of DNA linear duplex markers (a 50 basepair ladder).

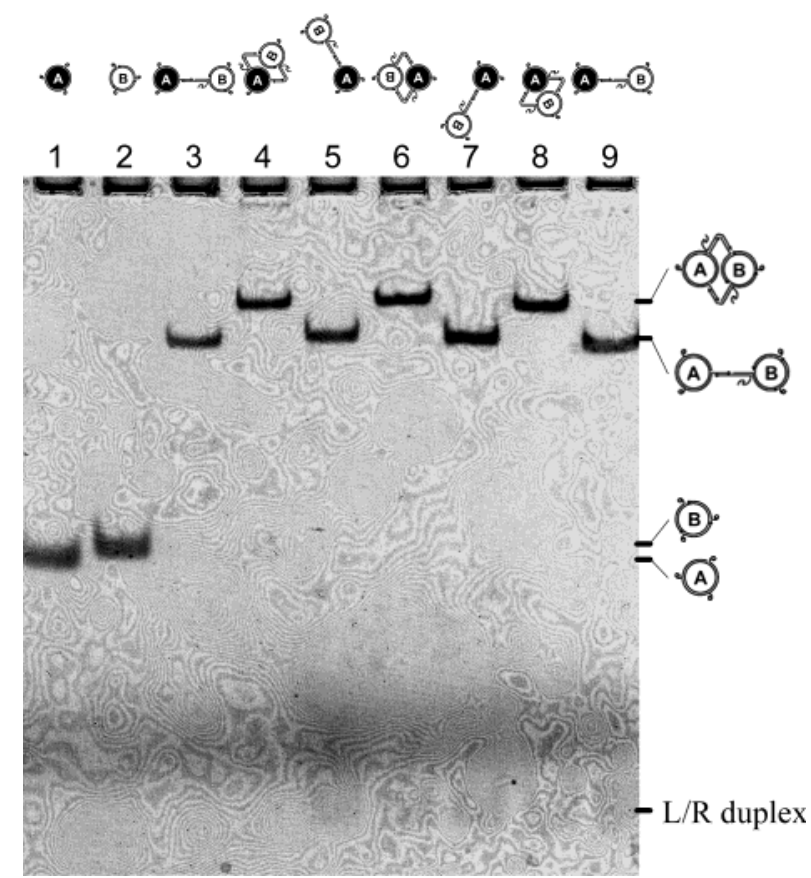

Figure 3. Native PAGE (6\%) analysis of the gear rolling process. The rolling state is indicated above each lane. The contents in the lanes are: 1: $\mathrm{A} ; 2: \mathrm{B} ; 3: \mathrm{A}+\mathrm{B}+\mathrm{L}_{1} ; 4: \mathrm{A}+\mathrm{B}+\mathrm{L}_{1}+\mathrm{L}_{2} ; 5: \mathrm{A}+\mathrm{B}+\mathrm{L}_{1}+\mathrm{L}_{2}+\mathrm{R}_{1}$; 6: $\quad \mathrm{A}+\mathrm{B}+\mathrm{L}_{1}+\mathrm{L}_{2}+\mathrm{R}_{1}+\mathrm{L}_{3} ; \quad$ 7: $\quad \mathrm{A}+\mathrm{B}+\mathrm{L}_{1}+\mathrm{L}_{2}+\mathrm{R}_{1}+\mathrm{L}_{3}+\mathrm{R}_{2} ; \quad 8$ : $\mathrm{A}+\mathrm{B}+\mathrm{L}_{1}+\mathrm{L}_{2}+\mathrm{R}_{1}+\mathrm{L}_{3}+\mathrm{R}_{2}+\mathrm{L}_{1} ; 9: \mathrm{A}+\mathrm{B}+\mathrm{L}_{1}+\mathrm{L}_{2}+\mathrm{R}_{1}+\mathrm{L}_{3}+\mathrm{R}_{2}+\mathrm{L}_{1}+\mathrm{R}_{3}$. In this experiment, gear $\mathrm{B}$ completes one cycle rolling around gear $\mathrm{A}$. The DNA solution incubates at $22{ }^{\circ} \mathrm{C}$ for $30 \mathrm{~min}$ before addition of the next DNA strand. The shadow crossing the lower part of the gel is from a gel tracking dye. Note that $\mathrm{L} / \mathrm{R}$ duplex waste accumulates during the process.

juxtaposed strands can be ligated into long strands, and all other strands remain unchanged. Once- and twice-linked states will produce one and two long strands, respectively. All peripheral DNA strands are designed with different length by adding different number of T's at the ends, so that we can easily identify the fate of all peripheral strands and determine the complex conformation. The results from ligation experiment are consistent with our expectation and clearly indicate that the gears roll against each other.

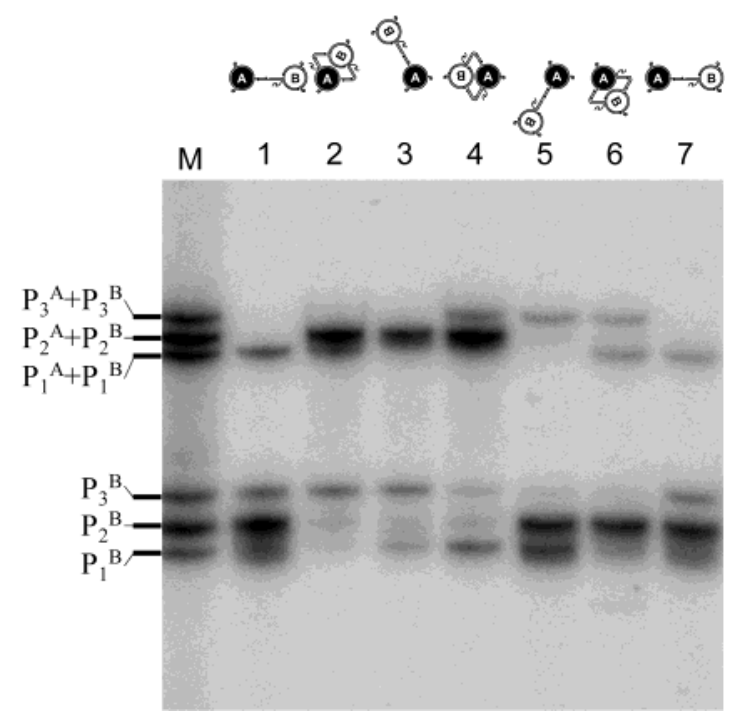

Figure 4. Denaturing PAGE (15\%) analysis of the gear rolling process. The reporter strands report the gear system conformation. The stage where ligation is performed is indicated above each lane. Lane $\mathrm{M}$ contains separately prepared single-stranded DNA size markers. Note that only isotope-labeled strands are visible.

In summary, we have constructed a molecular gear system and demonstrated that the gears could continuously roll against each other. This work, along with the recently reported walkers, ${ }^{2 k, l}$ represents an initial step to construct DNA nanomachines that could perform complicated motions. Complicated nanomachines are expected to contain multiple simple motors that can efficiently communicate with each other and cooperatively work together. The tool to build complicated machines is already available: it is structural DNA nanotechnology. ${ }^{1}$ Through engineered DNA nanostructures, we could potentially organize many individual DNA motors to form complicated nanomachines.

Acknowledgment. This work was supported by NSF (EIA0323452), DARPA/DSO (MDA 972-03-1-0020), and Purdue University (a startup fund).

Supporting Information Available: Experimental methods and DNA sequences. This material is available free of charge via the Internet at http://pubs.acs.org.

\section{References}

(1) (a) Seeman, N. C. J. Theor. Biol. 1982, 99, 237-247. (b) Seeman, N. C Biochemistry 2003, 42, 7259. (c) Seeman, N. C. Nature 2003, 421, 427.

(2) (a) Mao, C.; Sun, W.; Shen, Z.; Seeman, N. C. Nature 1999, 397, 144. (b) Yurke, B.; Turberfield, A. J.; Mills, A. P.; Simmel, F. C.; Neumann, J. L. Nature 2000, 406, 605. (c) Yan, H.; Zhang, X.; Shen, Z.; Seeman N. C. Nature 2002, 415, 62. (d) Li, J. J.; Tan, W. Nano Lett. 2002, 2, 315. (e) Simmel, F. C.; Yurke, B. Appl. Phys Lett. 2002, 80, 883. (f) Alberti, P.; Mergny, J. Proc. Natl. Acad. Sci. U.S.A. 2003, 100, 1569. (g) Turberfield A. J.; Mitchell, J. C.; Yurke, B.; Mills, A. P., Jr.; Blakey, M. I.; Simmel, F. C. Phys. Rev. Lett. 2003, 90, 118102-1. (h) Feng, L.; Park, S. H.; Reif, J. H.; Yan, H. Angew. Chem., Int. Ed. 2003, 42, 4342. (i) Liu, D.; Balasubramanian, S. Angew. Chem., Int. Ed. 2003, 42, 5734. (j) Chen, Y.; Wang, M.; Mao, C. Angew. Chem., Int. Ed. 2004, 43, 3554. (k) Sherman, W.; Seeman, N. C. Nano Lett. 2004, 4, 1203. (1) Shin, J.-S.; Pierce, N. A. In Preliminary Proceedings of the Tenth International Meeting on DNA Computing, Milan, Italy, June 2004; Ferretti, C., Mauri, G., Zandron, C., Eds.; p 46. (m) Chen, Y.; Mao, C. J. Am. Chem. Soc. 2004, 126, 8626 .

(3) Nice, K. How Gear Work. HowStuffWorks Web Site, accessed August 12, 2004. http://science.howstuffworks.com/gear.htm.

JA046507H 